\title{
Paleotemperature reconstruction using environmental isotopes and noble gases in groundwater in Morocco
}

\author{
Marianna Túri ${ }^{1,2} \cdot$ Radouan Saadi $^{3} \cdot$ Hamid Marah $^{3} \cdot$ Marjan Temovski $^{1} \cdot$ Mihály Molnár $^{1} \cdot$ László Palcsu $^{1}$
}

Received: 14 March 2019 / Accepted: 19 January 2020 / Published online: 5 February 2020

(C) The Author(s) 2020

\begin{abstract}
A Turonian limestone-dolomite aquifer from the Tadla basin of Morocco was analysed using a multi-tracer approach $\left(\delta^{18} \mathrm{O}, \delta^{2} \mathrm{H}\right.$, $\delta^{13} \mathrm{C},{ }^{3} \mathrm{H},{ }^{14} \mathrm{C}$ and noble gases) to reconstruct the paleotemperature evolution from the late Pleistocene to the Holocene. The Turonian aquifer was found to be suitable for a groundwater-based paleoclimate reconstruction, representing the Holocene-late Pleistocene epochs. After correction for young water contribution, mean residence times (MRTs) of groundwater were calculated using the Pearson radiocarbon model. Additionally, terrigenic helium content was used as an age indicator. Noble gas temperature (NGT) results from wells with groundwater ages corresponding to glacial periods showed an average of $17.2 \pm 1.7^{\circ} \mathrm{C}$. In contrast, samples of recent recharge water gave a mean NGT of $25.2 \pm 1.3^{\circ} \mathrm{C}$. This reveals a temperature difference of $8.0 \pm 2.1^{\circ} \mathrm{C}$ between the Holocene and late Pleistocene. This significant Pleistocene-Holocene temperature difference observed in Africa has considerable significance and can be extended to address an important topic relating to the nature of the wet epochs during which the fossil aquifers of North Africa were recharged. It is evident that this aquifer was recharged during both interglacial (warm) and glacial (cool) wet periods.
\end{abstract}

Keywords Noble gas $\cdot$ Paleohydrology $\cdot$ Radiocarbon $\cdot$ Stable isotopes $\cdot$ Morocco

\section{Introduction}

Valuable paleoclimatic information can be derived from the investigation of environmental isotopes and noble gases in groundwater. Noble gas solubility in groundwater is a useful method to reconstruct the recharge temperature, which together with groundwater dating is a very powerful tool for paleoclimatic reconstruction. This is a direct and quantitative

Electronic supplementary material The online version of this article (https://doi.org/10.1007/s10040-020-02121-1) contains supplementary material, which is available to authorized users.

Marianna Túri

turi.marianna@atomki.mta.hu

1 Isotope Climatology and Environmental Research Centre, Institute for Nuclear Research, Hungarian Academy of Sciences, Bem tér 18/ C, Debrecen H-4026, Hungary

2 Department of Mineralogy and Geology, University of Debrecen, Egyetem tér 1, Debrecen H-4010, Hungary

3 Centre National de l'Energie, des Sciences et Techniques Nucléaires (CNESTEN), Rabat, Morocco, 65 rue Tansift, Agdal,

Rabat, Morocco method to reconstruct past mean annual temperature by measuring noble gas concentrations and radiocarbon or other age indicators in groundwater. This approach provides the soil temperature at which the water recharged to the aquifer (Stute and Schlosser 1993; Aeschbach-Hertig et al. 1999; Klump et al. 2007; Varsányi et al. 2011; Aeschbach-Hertig and Solomon 2013). Although such groundwater studies exist for Africa, the data coverage is poor and general knowledge is still scarce on reconstructions of groundwater recharge temperatures (e.g. Rudolph et al. 1984; Heaton et al. 1986; Darling et al. 1987; Fontes et al. 1993; Andrews et al. 1994; Edmunds et al. 1998; Guendouz et al. 1998; Beyerle et al. 2003; Kulongoski et al. 2004; Abouelmagd et al. 2014).

Several paleoclimatological methods have been used to reconstruct past climate on decadal or annual timescales during the last few decades. These are usually based on $\delta^{18} \mathrm{O}$ records in polar ice cores, or laminated sediments from marine or terrestrial environments. These proxies, such as those in marine sediments accumulating along the margins of the African continent, provide information on African paleoclimate history, and are unique records of past global climate (Stuiver and Grootes 2000; Martrat et al. 2004; Darling 2011; Berke et al. 2012; Loomis et al. 2012; de 
Menocal 2014; Wu et al. 2017). Temperature reconstruction together with age determination are generally used to study climate conditions and similar paleoclimate records have been published from the continent (Namibia, Oman, Niger, Botswana, Egypt) (Stute and Talma 1998; Weyhenmeyer et al. 2000; Beyerle et al. 2003; Kulongoski et al. 2004; Abouelmagd et al. 2014).

In this paper, a limestone-dolomite aquifer was studied in the Tadla basin, Morocco, where environmental isotopes $\left(\delta^{18} \mathrm{O}, \delta^{2} \mathrm{H}, \delta^{13} \mathrm{C},{ }^{3} \mathrm{H},{ }^{14} \mathrm{C}\right)$ and noble-gas investigations were used in the Turonian aquifer to determine the annual temperature of the late Pleistocene and Holocene periods. Although similar isotope hydrological studies exist for Tadla basin (Bouchaou et al. 2009; Bouhlassa 2010; Saadi et al. 2017), the data coverage is poor and information about the groundwater recharge conditions in the basin is still incomplete. The multi-layered aquifer system in the Tadla basin constitutes one of the main water resources in Morocco and the purpose of this investigation is to expand the hydrological knowledge of the Turonian aquifer by analysing the recharge conditions, the age distribution and the isotope characteristics of the groundwater. The aim in this study is to interpret the noble gas data in terms of paleoclimate reconstruction, which has the potential to make significant contribution to the discussion on climate evolution and past groundwater dynamics in Morocco.

\section{Study area}

The Turonian aquifer is located in central Morocco in the Tadla basin $\left(5,000 \mathrm{~km}^{2}\right)$ and is part of a multi-layer aquifer system (Mio-Plio-Quaternary, the Maastrichtian-Eocene, the Senonian and the Turonian) of the Oum Er-Rabia basin. The Turonian aquifer is formed in the north by karstic limestone and dolomite, and is characterized mostly by dolomite in the south. It is one of the main water resources with high production rates up to $1,300 \mathrm{l} / \mathrm{s}$ in the basin, and is among the most important aquifer sources in Morocco (Bouchaou et al. 2009). It is under an impermeable marl formation of Cenomanian. The thickness of the Turonian formation ranges from $50 \mathrm{~m}$ (in the north) to $100 \mathrm{~m}$ (in the south). Most of the wells and boreholes are in the confined part, except in the locations of well samples 1,2 and 3, which are in the recharge area located in the unconfined part of the aquifer. The climate is warm and temperate in the basin and it is considered to be a hot-summer Mediterranean climate (Csa) according to the Köppen-Geiger climate classification. The annual precipitation is $550 \mathrm{~mm}$, and the most rainfall occurs between October and April with precipitation of $60-85 \mathrm{~mm} /$ month. The driest months are in summer (July, with $2 \mathrm{~mm}$ of rainfall). The annual average temperature is about $19{ }^{\circ} \mathrm{C}$. The warmest month of the year is July, with an average temperature of $29.5^{\circ} \mathrm{C}$. The lowest average temperatures in the year occur in January, when it is around $10.5^{\circ} \mathrm{C}$ (Climate-data.org, 1982-2012).
The potential of the Turonian aquifer as a paleoclimate archive was described in detail in a preliminary study of this area (Saadi et al. 2017), where the direction of flow paths to the south and south-west from the outcrop zone, based on stable isotope values, had been confirmed. Moving away from the outcrop zone, the stable isotope values became increasingly depleted along the existing flow lines as radiocarbon and tritium concentrations decrease. It had been concluded there that the Turonian aquifer might be a potential place for late Pleistocene-Holocene paleoclimate reconstruction from groundwater studies, since the mean residence times of water along the flow path was increasing and this confirmed the existence of the paleowater in the Turonian aquifer. To find paleowater, it is desirable to extend groundwater sampling of the aquifer along the direction of the flow-path. The sampled points in the basin used as part of this study covered over $3,500 \mathrm{~km}^{2}$ between Boujad, Oulad Zmam and El Borouj (Fig. 1) and according to the flow paths the screen depth of the sampled points are continuously decreasing (Table 1).

\section{Analytical methods}

Nineteen groundwater samples were taken for noble gas, tritium, radiocarbon, and stable isotope analyses by researchers from the CNESTEN (Centre National de 1'Energie des Sciences et Techniques Nucléaires, Morocco) and ICER (Isotope Climatology and Environmental Research Centre, Hungary) laboratories. The samples were collected from artesian boreholes and wells (Fig. 1). Water temperature, $\mathrm{pH}$, electrical conductivity as well as alkalinity were measured in the field. The major ions were determined at CNESTEN with ion chromatography, atomic spectroscopy and titration, where $\mathrm{HCO}_{3}{ }^{-}( \pm 1.0 \%), \mathrm{Cl}^{-}( \pm 1.7 \%), \mathrm{NO}_{3}{ }^{-}( \pm 1.9 \%), \mathrm{SO}_{4}{ }^{2-}( \pm 2.0 \%)$, $\mathrm{Ca}^{2+}( \pm 1.1 \%), \mathrm{K}^{+}( \pm 0.9 \%), \mathrm{Na}^{+}( \pm 1.3 \%)$, and $\mathrm{Mg}^{2+}( \pm 0.9 \%)$ were measured (the numbers in parenthesis refers to the relative standard deviation RSD of the analyses).

Carbon stable isotope analyses of dissolved inorganic carbon (DIC) from the water samples were carried out with an automated GASBENCH II sample preparation device attached to a Thermo Finnigan Delta ${ }^{\text {Plus }}$ XP mass spectrometer (Vodila et al. 2011) at the ICER laboratory. Hydrogen and oxygen stable isotopes of the water were measured with a Picarro (L2130-i) at CNESTEN and they are expressed as $\delta^{2} \mathrm{H}, \delta^{18} \mathrm{O}$, and $\delta^{13} \mathrm{C}$ values relative to VSMOW and VPDB, respectively, following the equation: $\delta=\left(R_{\text {sample }} / R_{\text {standard }}-1\right.$; expressed in permil), where $R$ is the ${ }^{2} \mathrm{H} /{ }^{1} \mathrm{H},{ }^{18} \mathrm{O} /{ }^{16} \mathrm{O}$ or ${ }^{13} \mathrm{C} /{ }^{12} \mathrm{C}$ ratios in the sample or in the international standards. Measurement precision is better than $\pm 0.1 \%$ or for $\delta^{18} \mathrm{O}$ and $\delta^{13} \mathrm{C}$, and $\pm 1 \%$ oror $\delta^{2} \mathrm{H}$.

Groundwater samples were treated in vacuum-tight septasealed reactors for AMS (accelerator mass spectrometry) ${ }^{14} \mathrm{C}$ analyses. First, $20 \mathrm{ml}$ of the groundwater sample was injected 


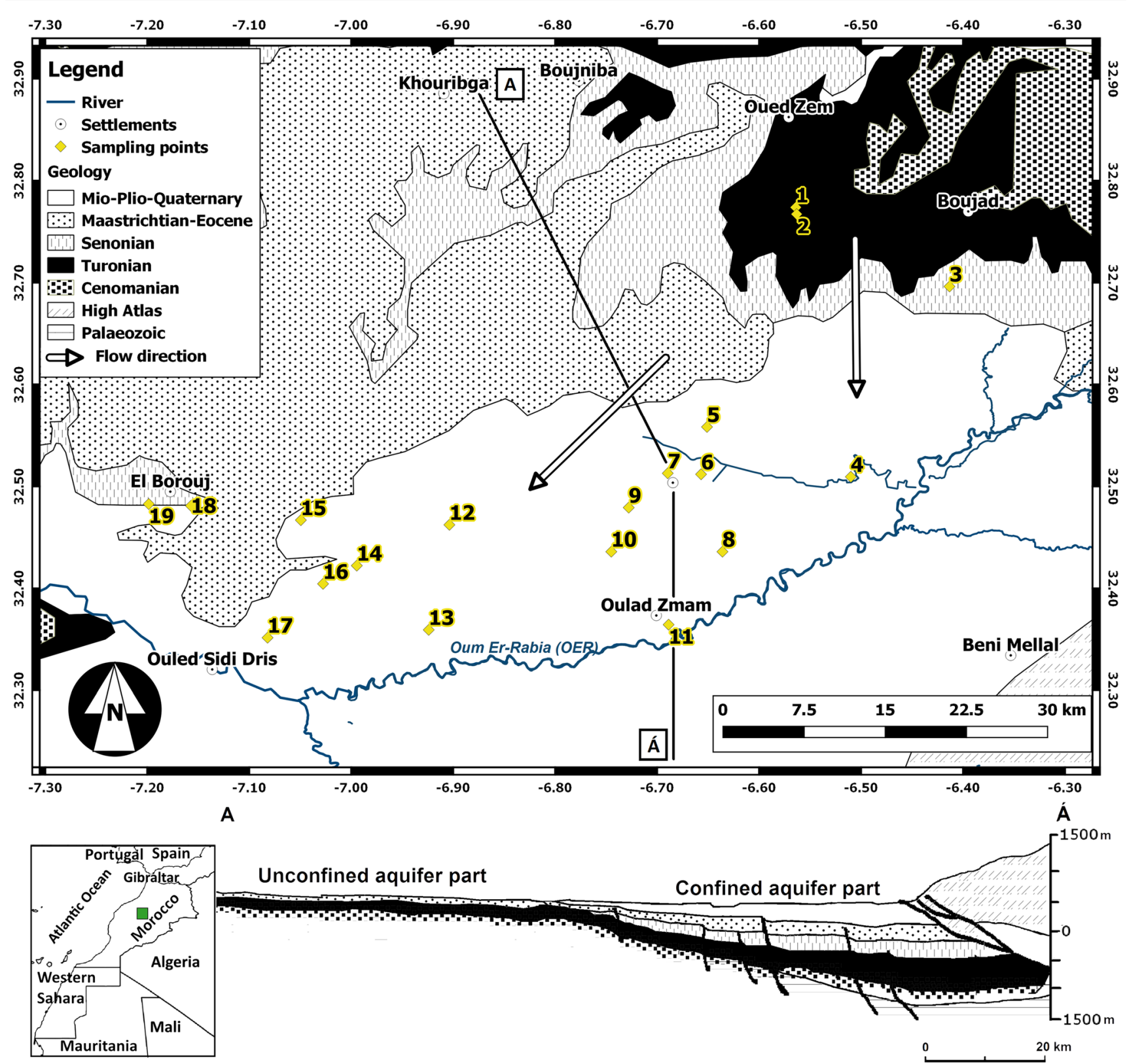

Fig. 1 A simplified geological map of the Tadla basin with sampling points of wells and boreholes, and a North-South cross section (Tammal et al. 2014)

into the evacuated reaction cell and, in a second step, $3 \mathrm{ml}$ of $85 \%$ phosphoric acid was introduced into the cell, via the septum by disposable sterile medical plastic syringes. Then the water and acid mixture at the bottom of the reaction cell was heated to $75^{\circ} \mathrm{C}$ in a heating block for at least $1 \mathrm{~h}$ to increase the rate of reaction and improve $\mathrm{CO}_{2}$ extraction yield from DIC fraction. The $\mathrm{CO}_{2}$ produced off-line was then introduced into the in-line $\mathrm{CO}_{2}$ gas purification system (Molnár et al. 2013a). In a final step, AMS graphite targets were prepared from the purified $\mathrm{CO}_{2}$ samples using a customized sealed tube graphitization method, for ${ }^{14} \mathrm{C}$ analysis by the EnvironMICADAS AMS at ICER (Rinyu et al. 2013). The ${ }^{14} \mathrm{C}$ results are reported as percent modern carbon (pMC), calculated by the BATS software (version 3.66; Wacker et al. 2010). The overall ${ }^{14} \mathrm{C}$ measurement uncertainty for modern samples is $<0.3 \mathrm{pMC}$, including normalization, background subtraction, stable-isotope fractionation correction and counting statistics (Molnár et al. 2013b).

The water samples for dissolved noble gases analysis were collected in copper tubes in the field, sealed by stainless-steel pinch-off clamps. The water samples were introduced into a preparation line, where all the gases were adsorbed in two cryotraps. The heavy gases including argon, krypton, xenon and all chemically active gases $\left(\mathrm{N}_{2}, \mathrm{O}_{2}, \mathrm{CO}_{2}\right.$, etc.) were collected in a stainless steel trap (SST) at $25 \mathrm{~K}$, while helium and neon were collected in a charcoal trap $(\mathrm{CT})$ at $10 \mathrm{~K}$. Heating the CT up to 42 and $90 \mathrm{~K}$, allowed the helium and neon fraction to be determined sequentially. After releasing the 


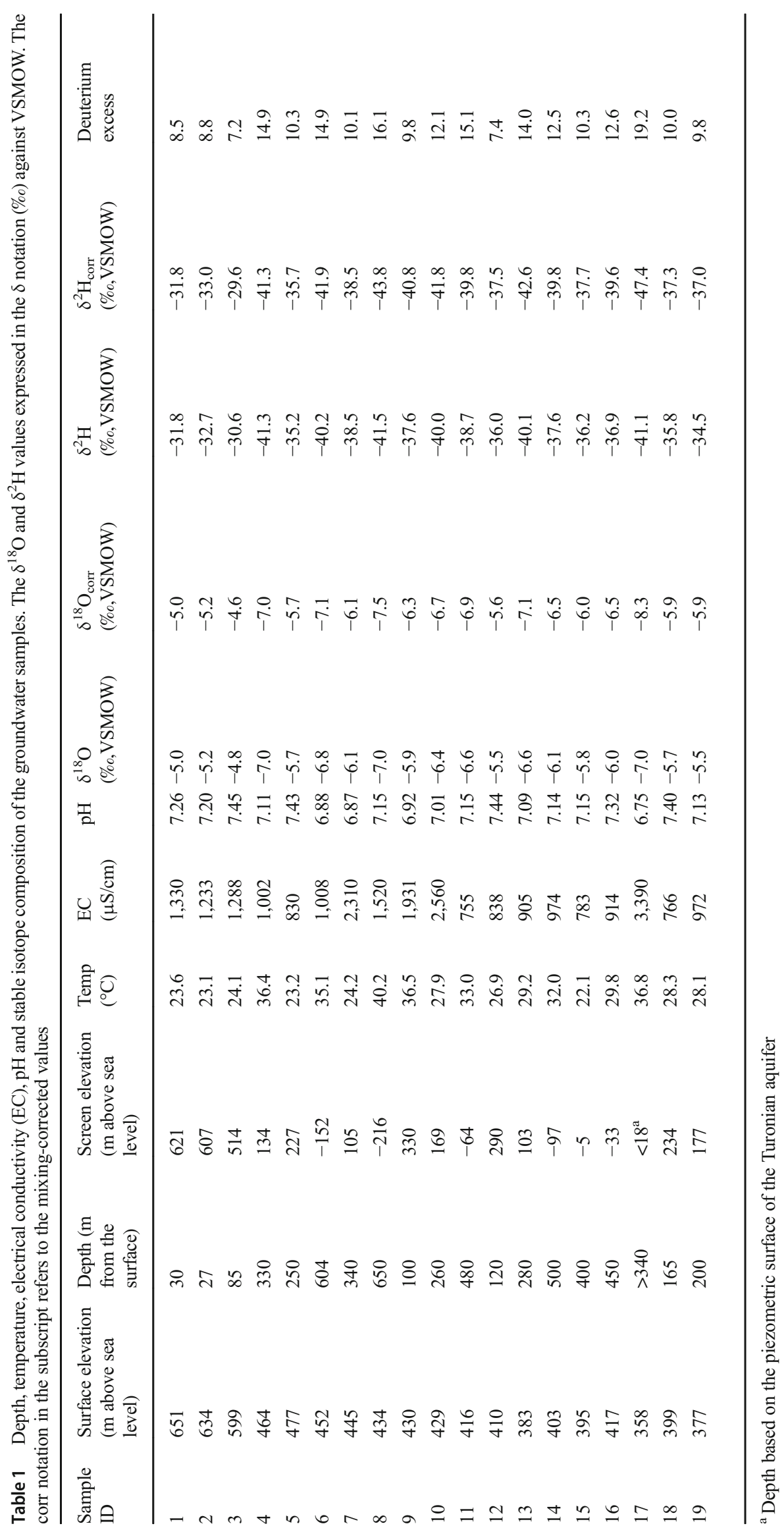


heavy gases from the SST at $150 \mathrm{~K}$, a tiny amount was purified with a SAES St707 getter cartridge. The pure argonkrypton-xenon fraction was then admitted to the mass spectrometer. The heavy noble gas (Ne-Ar-Kr-Xe) measurements were measured using a VG5400 (Fisons Instruments), while helium and ${ }^{3} \mathrm{He} /{ }^{4} \mathrm{He}$ were obtained using a Helix SFT (Thermo Scientific) noble gas mass spectrometer. The whole analysis was calibrated with known air aliquots with an accuracy of $1.0 \%$ for $\mathrm{He}, \mathrm{Ne}, \mathrm{Ar}$ concentrations and ${ }^{3} \mathrm{He} /{ }^{4} \mathrm{He}$ ratios, and $1.5 \%$ for $\mathrm{Kr}$ and $\mathrm{Xe}$ concentrations (Papp et al. 2012). The accuracies allow for calculation of noble gas temperatures (NGTs) with a precision better than $0.5^{\circ} \mathrm{C}$.

Tritium concentrations were measured using batches of electrolysis cells, which were developed for tritium enrichment in water samples to increase its concentration, followed by liquid scintillation counting using Quantulus 1220 (Perkin Elmer), in CNESTEN (Marah 2007). The results are expressed in tritium units (TU) and the precision of the tritium measurements were better than $0.5 \mathrm{TU}$.

\section{Results and discussion}

\section{Chemical characterisation of the groundwater}

The water chemistry is useful for the radiocarbon dating model and also helps understand and demonstrate that the samples come from the same aquifer, have similar groundwater dynamics, and which samples derive from the same flow-path. Both shallow and deep wells were sampled, with water samples collected from the outcrop zone at depths of 27 and $30 \mathrm{~m}$ and from deeper parts along the flow path, between depths of 100-650 m. Water temperatures varied between 22.1 and $40.2{ }^{\circ} \mathrm{C}$, and the aquifer is generally characterised by neutral $\mathrm{pH}$ ranging from 6.75 to 7.45 . The main chemical parameters of the groundwater samples are summarized in Table S1 of the electronic supplementary material (ESM).

Groundwater quality depends on water-rock interaction mechanisms between the Turonian karstic limestone/ dolomite and water. General groundwater characteristics based on major ions are illustrated in a Piper diagram (Fig. $\mathrm{S} 1$ of the ESM). The groundwater in the Turonian aquifer is mainly characterised by $\mathrm{Ca}-(\mathrm{Mg})-\mathrm{HCO}_{3}$ waters. One group, located in the middle part of the study area (samples 7, 8, 9, 10 ) has slightly more sulphate and chloride. The chemical composition of these waters indicates that the samples come from the same aquifer, which has a unique geochemical character. Sample 17 has $\mathrm{SO}_{4}-\mathrm{Cl}$ groundwater character based on dissolved anions, with relatively high $\mathrm{SO}_{4}$ content, being the only outlier of the groundwater samples. This water might not belong to the Turonian aquifer. In terms of radiocarbon dating, the carbonate will evolve along the flow path, which is characterized by a slight decrease in $\mathrm{HCO}_{3}{ }^{-}$in the area of the unsaturated zone (samples 1, 2, 3, 4). Further downstream the $\mathrm{HCO}_{3}{ }^{-}$remains almost stable along the flow path (between 5 and $6 \mathrm{mmol} / \mathrm{L}$ ). Ionic balance was calculated to observe any deviation from electrically neutral water based on all measured anions and cations, with differences less than 5.2\% (Table S1 of the ESM). This deviation is partly due to the use of multiple instruments for ion analyses leading to an accrual of analytical errors, and/or the lack of measurement of some ions (such as ammonium ion in this case).

\section{Radiocarbon dating of the groundwater}

To estimate groundwater residence time, it is necessary to consider partitioning processes at the boundary of the unsaturated and saturated zone, water-rock interactions and mixing processes to correct for potential addition of nonatmospheric carbon. Over the years, many theories and calculations have been developed to obtain accurate groundwater ages from ${ }^{14} \mathrm{C}$ measurements of dissolved inorganic carbon (Ingerson and Pearson 1964; Fontes and Garnier 1979; Mook 1980; Salem et al. 1980; Blaser et al. 2010; Varsányi et al. 2011; Plummer and Glynn 2013; Han and Plummer 2013). Ideally, radiocarbon dating of groundwater can be performed in cases when the chemical parameters do not change significantly along the flow path within the aquifer. For this study, first the proportion of freshwater (as indicated by the presence of tritium) was calculated and based on the freshwater proportion, a mixing correction has been made for the measured components $\left(\delta^{18} \mathrm{O}\right.$, $\delta^{2} \mathrm{H}, \delta^{13} \mathrm{C},{ }^{3} \mathrm{H},{ }^{14} \mathrm{C}, \mathrm{HCO}_{3}{ }^{-}$and noble gases). The Pearson model was used for radiocarbon dating of groundwater based on mixing corrected values.

Surprisingly, the natural dynamics of this groundwater system is affected by mixing with freshwater, even at the confined part of the aquifer. This freshwater input is indicated by the presence of tritium, an isotope tracer capable of giving complementary information to understand and quantify freshwater contributions to the aquifer. As one can see in Table 2, the tritium concentrations of most of the samples in the confined aquifer are between 0.5 and $1.9 \mathrm{TU}$, having ${ }^{14} \mathrm{C}$ concentrations between 12 and $73 \mathrm{pMC}$. In general, considering the long mean residence time (MRT) based on the Pearson ${ }^{14} \mathrm{C}$ model (Table 2), the aquifer should not contain any trace of freshwater. A possible source of this freshwater contamination is from mixing of shallow groundwater with the Eocene aquifer through faults, incorrect well construction or multiscreen wells (Fig. 1). This contamination may occur due to overexploitation of the aquifer, causing high local water-table depression.

To estimate mixing proportions of groundwater samples, the first step is to calculate the freshwater contribution using the tritium content of the samples (Table 2). The determination of the freshwater/old-water proportion is calculated by the expected initial and measured tritium values of the 


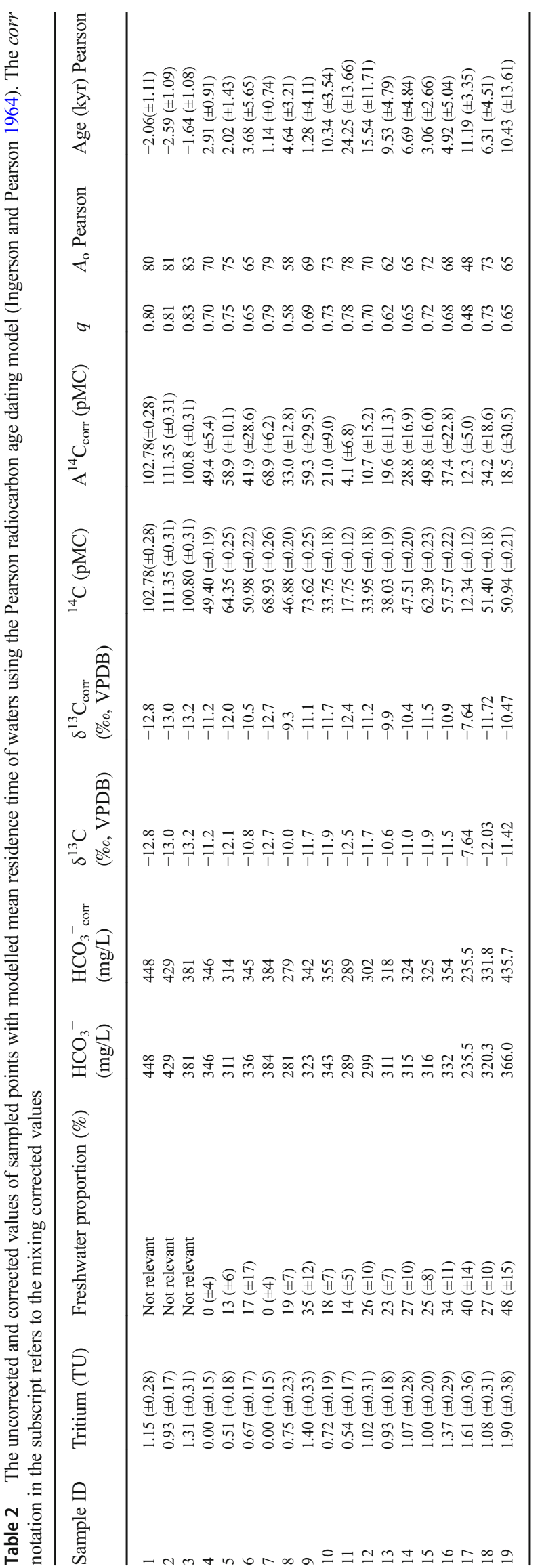

groundwater sample. The initial tritium content of water is assumed to be 4TU according to the IAEA GNIP station data of Fes Sais and tritium content of Oum Er-Rabia (OER) river (IAEA and WMO 2014; Bouhlassa 2010). In both cases, the average annual precipitation and the average annual river water have a tritium concentration of 4 TU. The GNIP station in Fes Sais is only about $300 \mathrm{~km}$ from the Tadla basin, and at the same distance from the Atlantic Ocean; hence, the $4 \mathrm{TU}$ is a reliable estimate for the local precipitation in this study area. However, the freshwater contribution might not be necessarily absolute recent, while tritium might be derived from bomb peak. It might have recharged during the last 0-60 years, when the tritium concentration of the precipitation (mainly in the northern hemisphere and continental areas) was much higher due to the thermonuclear bomb tests. Unfortunately, there are only tritium data for the GNIP station Fes Sais available from 1994 to 2000; earlier values have not been reported. The recent value for the precipitation and the OER river, $4 \mathrm{TU}$, might be considered as a reliable value for the earlier precipitation, when the radioactive decay is taken into account. However, an uncertainty of $1 \mathrm{TU}$ to the freshwater contribution (4 TU) is therefore added to the calculation. To calculate the mixing ratios, the following equation is applied: freshwater proportion $($ in $\%)=\left(\right.$ Tritium $_{\text {measured }} /$ Tritium $\left._{\text {initial }}\right) \cdot 100$, assuming that the old component has no tritium.

The principle of radiocarbon dating of groundwater is that precipitation enters the aquifer through the unsaturated zone and dissolves $\mathrm{CO}_{2}$ from the soil gas, which is produced by root respiration (Clark and Fritz 1997; Geyh 2000; Mook 2000). Therefore, it is assumed to be modern at $100 \mathrm{pMC}$ ${ }^{14} \mathrm{C} . \mathrm{CO}_{2}$ dissolution forms carbonic acid, which in turn, dissolves carbonate mineral species in the aquifer sediments to produce dissolved inorganic carbon (DIC), which stands for $\mathrm{CO}_{2(\mathrm{aq})}+\mathrm{HCO}_{3}{ }^{-}+\mathrm{CO}_{3}{ }^{-2}$. The ${ }^{14} \mathrm{C}$ content of DIC in groundwater begins to decrease with a half-life of 5,730 years after the isolation from the modern ${ }^{14} \mathrm{C}$ reservoir, when the groundwater enters the saturated zone. The main questions in radiocarbon age models are the estimation of the initial radiocarbon concentration and what happens along the groundwater flowline. Because of the dissolution of ${ }^{14} \mathrm{C}$-free carbonate along the flow-line, the DIC does not reflect the atmospheric ${ }^{14} \mathrm{C}$ activity plus the effect of radioactive decay. Different radiocarbon age models estimate the initial ${ }^{14} \mathrm{C}$ content $\left(A_{0}\right)$ of DIC in groundwater at recharge in different ways (Ingerson and Pearson 1964; Fontes and Garnier 1979; Mook 1980; Salem et al. 1980; Plummer and Glynn 2013). The usual way in groundwater hydrology to calculate the groundwater apparent age is to apply the following equation: $t=8267 \ln \left(A_{0} / A_{t}\right)$, where $t$ is the radiocarbon age, $A_{0}$ is the initial and $A_{t}$ is the measured radiocarbon activity in the dissolved inorganic carbon, where the mean life-time of radiocarbon is 8,267 years.

According to the Pearson model, a dilution factor $(q)$ can be calculated to estimate the proper $A_{0}$ from the radiocarbon 
content of atmospheric and soil $\mathrm{CO}_{2}$. This dilution factor $(q)$ can be calculated by using the equation of $q=\left(\delta^{13} \mathrm{C}_{\mathrm{DIC}}-\right.$ $\left.\delta^{13} \mathrm{C}_{\text {carb }}\right) /\left(\delta^{13} \mathrm{C}_{\text {soil }}-\delta^{13} \mathrm{C}_{\text {carb }}\right)$; in respect to this the $\delta^{13} \mathrm{C}_{\text {DIC }}$ is the measured carbon isotope ratio in groundwater, $\delta^{13} \mathrm{C}_{\text {carb }}$ is the $\delta^{13} \mathrm{C}$ of the dissolved carbonate (estimated to be $0 \%$ vs. VPDB), while $\delta^{13} \mathrm{C}_{\text {soil }}$ refers to $\mathrm{CO}_{2}$ in the soil gas (estimated to be $-16 \%$ vs. VPDB based on the $\mathrm{C} 4$ vegetation cover in the outcrop-zone). The radiocarbon content of the host rock is assumed to be $0 \mathrm{pMC}$ and that of the soil zone is $100 \mathrm{pMC}$ (Ingerson and Pearson 1964; Saadi et al. 2017).

The mixing-corrected values $(A)$ using the Pearson model were also calculated using tritium-based freshwater proportions following this equation: $=\left(100 \cdot A_{\text {measured }}-\right.$ freshwater proportion $\left.\cdot \mathrm{A}_{\text {initial }}\right) /(100$-freshwater proportion). The initial bicarbonate value was chosen to be $289 \mathrm{mg} / \mathrm{L}(4.7 \mathrm{mmol} / \mathrm{L})$, which was the average of the values from the Eocene aquifer (Bouchaou et al. 2009). The initial $\delta^{13} \mathrm{C}$ value is -13.02 (\%o vs. VPDB) which is the average $\delta^{13} \mathrm{C}$ value of samples in the area of the outcrop zone (samples 1,2,3). Although the accuracy of the radiocarbon measurements is just between 0.12 and $0.31 \mathrm{pMC}$, the uncertainty of the radiocarbon groundwater age is propagated from other factors, mainly from the mixing correction. Using the uncertainties of the individual tritium values as well as the $1 \mathrm{TU}$ uncertainty of the freshwater component, the uncertainty of the freshwater contribution can be calculated. As Table 2 shows, these uncertainties can be significantly high. This latter increases the uncertainty of the corrected radiocarbon content of the old component, and hence the error of the age also increases. These calculations are rather a conservative approach, and might overestimate the overall error; therefore, it is recommended to consider it carefully.

The same mixing correction approach was applied to determine the noble gas and stable isotope compositions of the old component of groundwater samples, where the initial values were chosen to be the average values in the area of the outcrop zone (samples 1, 2, 3). For the Pearson model, the mixing-corrected radiocarbon content was determined using a binary calculation based on the tritium-derived freshwater proportion and the mixing-corrected bicarbonate content. The modern recharge waters close to the outcrop zone (samples 1,2,3) are expected to contain tritium and so mixing corrections are not necessary for these waters. It must be noted that the values used in the Pearson model of sample 17 were not corrected for mixing, despite the fact that the water has some tritium, as the mixing correction did not give meaningful results for the mixed radiocarbon age. Additionally, based on the chemical composition, sample 17 is an outlier.

Besides the recently recharged samples from the outcrop zone of the Turonian aquifer, with radiocarbon content between 100 and $112 \mathrm{pMC}$ (samples 1,2,3), there are samples from the unconfined and confined part of the aquifer (samples $4,5,6,7,8,9,14,15,16,18$ ) with Holocene ages between 1 and 7 kiloyears (kyr) and there are samples with ages 9.5-24 kyr (samples 10,11, $1213,17,19$ ) closely correspond to the late Pleistocene. Although the calculated MRTs cover mostly the past 15,000 years, there are samples such as sample 11 with an age of about $25 \mathrm{kyr}$ and sample 17, which has a low radiocarbon content (and no mixing correction was used for sample 17); therefore, these locations might represent older ages between 15 and $25 \mathrm{kyr}$.

\section{Paleotemperature estimates from noble gases}

Noble gas concentrations are suitable temperature indicators at the time of groundwater recharge. In aquifers, the concentrations of $\mathrm{Ne}, \mathrm{Ar}, \mathrm{Kr}$ and $\mathrm{Xe}$ are derived from the atmosphere (as soil gas) and after their dissolution into the groundwater, their concentrations remain constant along the flow path, because they do not take part in either chemical or biological processes. The interpretation of noble gas concentrations in groundwater requires inverse modelling, which allows one to determine reliable solubility temperatures (noble gas temperatures, NGTs). As a gas partitioning model, the closed-system equilibration model (CE-model) was applied (AeschbachHertig et al. 1999, 2008; Aeschbach-Hertig and Solomon 2013). The main principle of the CE-model is that excess air is formed when the groundwater level is rising, and the soil gas bubbles are entrapped in the pore space. Afterwards, due to the increased hydrostatic pressure, the entrapped soil gas bubbles are totally or partly dissolved. When calculating the recharge temperature, an inverse modelling approach was used. During inverse modelling, parameters such as temperature, excess air and the fractionation of the excess air are varied, and the corresponding model concentrations are evaluated to determine which parameter setup provides the best estimates of the measured concentrations. In the case of the closed-system equilibration model, the model concentrations are calculated according to the following equation:

$$
\begin{aligned}
C_{i, \text { model }}(T, A, F, S, p) & =C_{i, \mathrm{eq}}(T, S, p)+C_{i, \mathrm{ex}}(T, A, F, S, p) \\
& =C_{i, \mathrm{eq}}+\frac{(1-F) \cdot A \cdot z_{i}}{1+\frac{F \cdot A \cdot z_{i}}{C_{i, e q}}}
\end{aligned}
$$

In this equation, the model concentration can be divided into two parts: a solubility equilibrium component $\left(C_{\text {eq }}\right)$ and an excess air component $\left(C_{\mathrm{ex}}\right)$. There are parameters that have to be assumed, like salinity $(S)$ and atmospheric pressure of the recharge area $(p)$. In case of recharging water, salinity can be neglected, while the prevailing atmospheric pressure can be calculated from the elevation of the recharge area. In this calculation, an average recharge elevation of $700 \mathrm{~m}$ asl has been chosen for all samples. The other parameters like temperature $(T)$, unfractionated excess air amount (or in case of the CEmodel, the entrapped air amount in the saturated zone) $(A)$, 


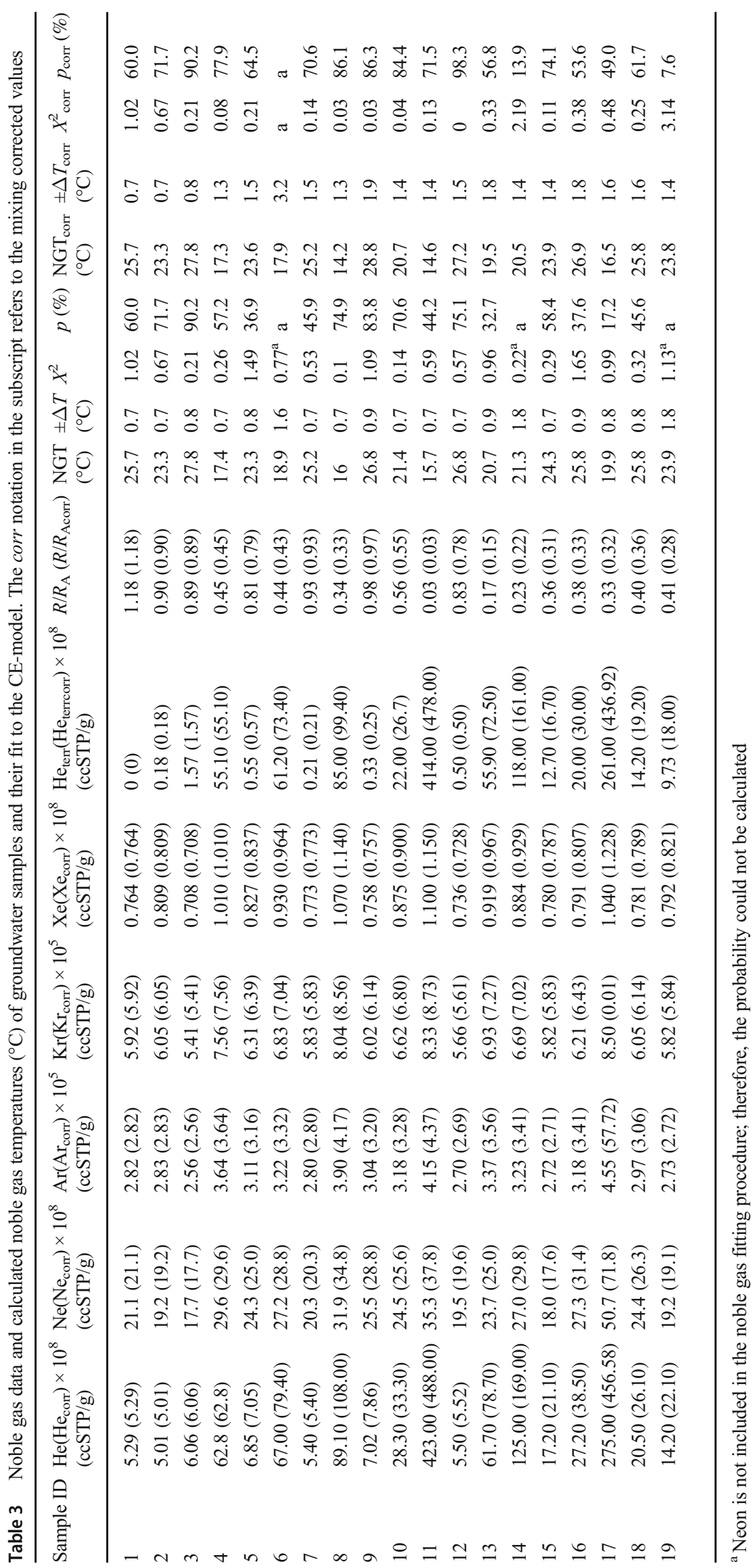


and the fractionation factor $(F)$ have to be estimated in the inverse modelling process. The index $i$ refers to the four atmospheric noble gases (neon, argon, krypton and xenon). Note that helium does not take part in the calculation, since it often has a significant terrigenic contribution. When searching for the best parameter set of $T, A$ and $F$, the calculated model concentrations are compared to the measured concentrations until the $\chi^{2}$ values reach a minimum. The $\chi^{2}$ value is defined in the following equation $\left(\sigma_{i}\right.$ is the analytical uncertainty of noble gas $i$ ):

$$
\chi^{2}=\sum_{i} \frac{\left(C_{i, \text { meas }}-C_{i, \text { model }}\right)^{2}}{\sigma_{i}^{2}} \quad(i: \mathrm{Ne}, \mathrm{Ar}, \mathrm{Kr}, \mathrm{Xe})
$$

The calculations have been performed with the Noble90 MATLAB routine (Peeters et al. 2003) and the Noblebook excel worksheet (Aeschbach-Hertig et al. 2000, 2008). The noble gas results are given in Table 3 and the mixingcorrected noble gas data can be found in Table 3 in parentheses. These latter datasets were exclusively used in subsequent interpretations. When the uncorrected noble gas concentrations are used in the inverse-fitting procedure, uncertainties of $1.5 \%$ for $\mathrm{Ne}, \mathrm{Kr}$ and $\mathrm{Xe}$, and $1.0 \%$ for $\mathrm{Ar}$ are included. Uncertainties of the mixing-corrected noble gas concentrations are twice as much than that of uncorrected values; hence, the NGTs calculated from mixing corrected noble gas concentrations have also higher uncertainties (about $1.5^{\circ} \mathrm{C}$ instead of $0.9^{\circ} \mathrm{C}$ ). Both calculations give significant results above the rigorous significance level of 0.1 . The mixing corrected noble gas data for all samples were used in the interpretation.

Water temperatures in the recharge area (samples 1, 2, 3) varied between 23.1 and $24.1{ }^{\circ} \mathrm{C}$, as measured in the field, which may reflect soil temperatures. These samples originating from the outcrop zone yielded an average noble gas temperature of $25.7 \pm 0.7^{\circ} \mathrm{C}$. This temperature is close to today's ground temperature $\left(23.6 \pm 0.5^{\circ} \mathrm{C}\right.$ ) (Bouchaou et al. 2009; Saadi et al. 2017), and can be correlated with the corresponding water temperatures which have been measured on the

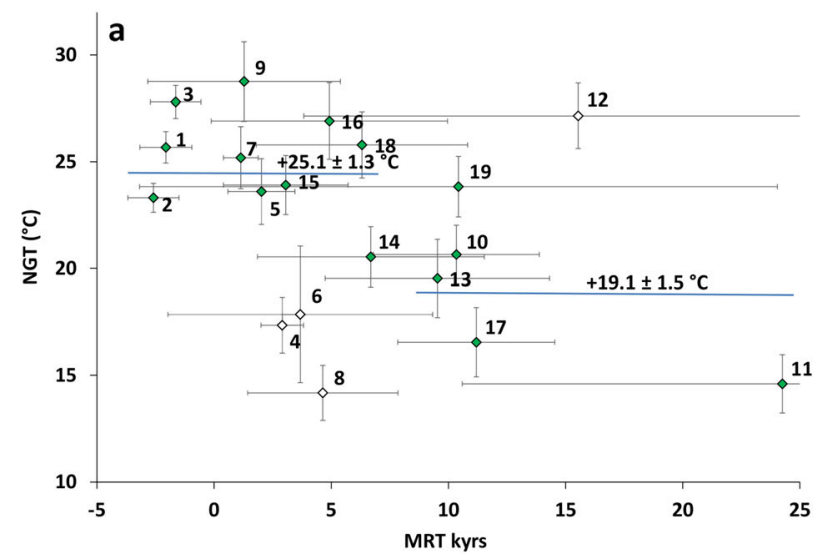

field. The NGTs are about $2{ }^{\circ} \mathrm{C}$ in excess of ground temperatures. This phenomenon can also be observed in temperate climate regions, where the soil temperature is slightly higher than the mean annual air temperature (Stute and Schlosser 1993; Stute et al. 1995), due to ground heating by incident solar radiation (Bartlett et al. 2006). In fact, the difference of soil and air temperature can be even higher in arid/semi-arid regions due to the lack of vegetation and the higher heat radiation (Beyerle et al. 2003; Aeschbach-Hertig and Solomon 2013). When evaluating water samples farther from the recharge area, the NGTs for the Holocene samples from modern to $7 \mathrm{kyr}$ (samples 1, 2, 3, 5, 7, 9, 14, 15, 16, 18), show an average of $25.1 \pm 1.3{ }^{\circ} \mathrm{C}$. The average NGT of samples between 9.5 and $24 \mathrm{kyr}$ in age is $19.1 \pm 1.5^{\circ} \mathrm{C}$ (samples 10, 11 , $12,13,17,19)$. These paleotemperatures are likely to correspond to glacial periods as the deduced recharge temperatures are considerably lower than Holocene temperatures in the Tadla basin. Based on the radiocarbon age classification, younger and older water samples can be relatively distinguished although there are some samples where the NGT clearly suggested to warmer (sample 12) or colder (samples $4,6,8$ ) periods in the past (Fig. 2a; Table 3), conceivably due to mixing.

In addition to the radiocarbon age classification, the terrigenous helium accumulation in groundwater can help for a distinction between Holocene and Pleistocene recharged waters and can help in questionable samples $(4,6,8,12$; Torgersen and Stute 2013). Helium represents another groundwater age indicator, which can contribute to a better understanding of MRTs of the groundwater samples. Groundwater samples often contain helium derived from other sources than the atmosphere (helium of crustal or mantle origin), and the ratio $R / R_{\mathrm{A}}$ (where $R$ and $R_{\mathrm{A}}$ are the ${ }^{3} \mathrm{He} /{ }^{4} \mathrm{He}$ ratio of the sample and air, respectively) generally decreases, while the helium concentration increases with longer MRTs (Gardner and Heilweil 2014). Hence, terrestrial ${ }^{4} \mathrm{He}\left({ }^{4} \mathrm{He}_{\text {terr }}\right)$ can be used to identifying old groundwater (Solomon 2000). NGTs plotted against the ${ }^{4} \mathrm{He}_{\text {terr }}$ content show that groundwater samples

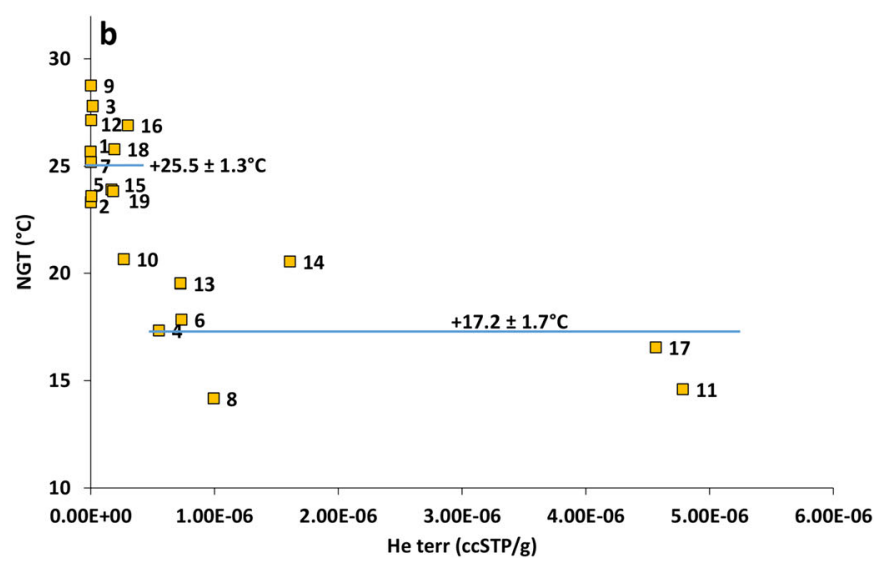

Fig. 2 a Noble gas temperature (NGTs) plotted versus mean residence times (MRTs); b NGTs plotted versus ${ }^{4} \mathrm{He}_{\text {terr }}$ 
with lower NGTs contain more ${ }^{4} \mathrm{He}_{\text {terr }}$ (Fig. 2b). This can be a useful tool to characterise the old fractions of groundwater especially in mixed samples; therefore, it is expected that groundwater samples with lower NGTs should have longer MRTs and a higher ${ }^{4} \mathrm{He}_{\text {terr }}$ content. Figure 2a,b show a similar pattern: the older the water, the higher the terrigenous helium component, and the lower the NGT. Two groups have been selected based on the radiogenic helium component: the first group with low radiogenic helium consists of samples 1, 2, 3, $5,7,9,12,15,16,18$, while the other group with high radiogenic helium consists of samples $4,6,8,11,13,14,17$. The average NGTs of the groundwater samples with radiogenic helium concentrations below and above $5 \cdot 10^{-7} \mathrm{ccSTP} / \mathrm{g}$ (defined arbitrarily) are $25.2 \pm 1.3{ }^{\circ} \mathrm{C}$ and $17.2 \pm 1.7^{\circ} \mathrm{C}$. Thus, the samples with the lowest NGTs of $14.2^{\circ} \mathrm{C}$ and $14.6^{\circ} \mathrm{C}$ (samples 8,11 ) indicate that their recharge occurred during the coldest glacial periods. As a result, the temperature difference between the Holocene and the late Pleistocene is $8.0 \pm 2.1^{\circ} \mathrm{C}$. Based on the terrigenous helium age classification, younger and older water samples can be more clearly distinguished and samples where the NGT clearly suggested to warmer or colder periods in the past can be more precisely distinguished. The samples are in two groups, one with warm young Holocene recharged water samples and the other with cold old Pleistocene recharged samples.

Similar to this study, past continental climatic changes have been confirmed by NGTs in several areas of Africa and the surrounding regions. A warming of at least $5{ }^{\circ} \mathrm{C}$ from the late Pleistocene to the Holocene was reconstructed in other studies in Africa. This signal can be seen in the Uitenhage artesian aquifer in South Africa (Heaton et al. 1986) and in Namibia (Stute and Talma 1998), as well as in groundwater samples from the Kalahari Desert in Botswana (Kulongoski et al. 2004). More intense warming $\left(6-7^{\circ} \mathrm{C}\right)$ was revealed by NGTs in Niger (Beyerle et al. 2003) and in the surrounding region of Africa in Oman (Weyhenmeyer et al. 2000). There are recharge temperatures from the northeastern region of Africa (Egypt), where deglacial warming of a similar magnitude $\left(2-7^{\circ} \mathrm{C}\right)$ was observed (Abouelmagd et al. 2014). These significant Pleistocene-Holocene temperature differences observed in Africa are noteworthy and can address the nature of the wet periods during which the fossil aquifers of North Africa were recharged. These aquifers were largely recharged during interglacial wet periods, as well as glacial wet periods. Previous studies have shown that even Holocene waters can show a cooler recharge (Beyerle et al. 2003). The large temperature difference between recent soil temperature and NGTs has been interpreted as being due to the impact of changes in soil temperature in the early-mid Holocene "green Sahara" period. The "outlier" samples in this study, like samples 4, 6, 8 and 14 (or even 10, 13 and 17), might represent the same effect (Fig. 2a). These samples seem to be recharged during the Holocene, only the mixing correction shifts the ages of these samples to around $10 \mathrm{kyr}$, and without this correction most of them would be clearly of early Holocene age.

\section{Groundwater stable isotope compositions}

Stable isotope values were corrected for mixing using the calculated mixing proportions and the initial values taken as average delta values for the recharge area (samples 1, 2, 3); these mixing corrected values were used in the interpretations. The oxygen stable isotope values are plotted against deuterium values for the whole study area (Fig. 3; Table 1). The majority of points fall on or around the global and the local meteoric water lines (GMWL and LMWL), with the latter defined by the equation $\delta^{2} \mathrm{H}=7.92 \cdot \delta^{18} \mathrm{O}+9.87$ (Brahim et al. 2016). Groundwater samples from the area of the outcrop zone (samples 1, 2,3) with modern recharge display the highest stable isotope compositions, and lie somewhat off the
Fig. $3 \delta^{2} \mathrm{H}$ is compared to $\delta^{18} \mathrm{O}$. GMWL Global Meteoric Water Line, LMWL local meteoric water line; the stable isotope values are expressed as $\delta$ notation in \%o compared to Vienna Standard Mean Ocean Water (VSMOW)

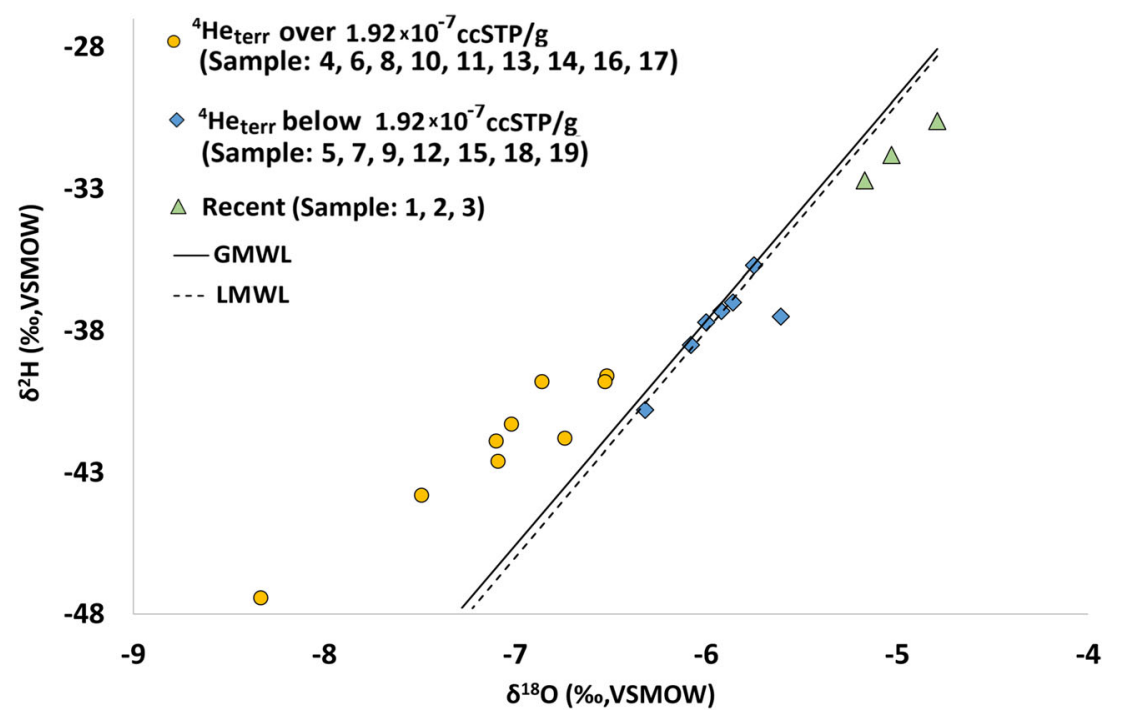



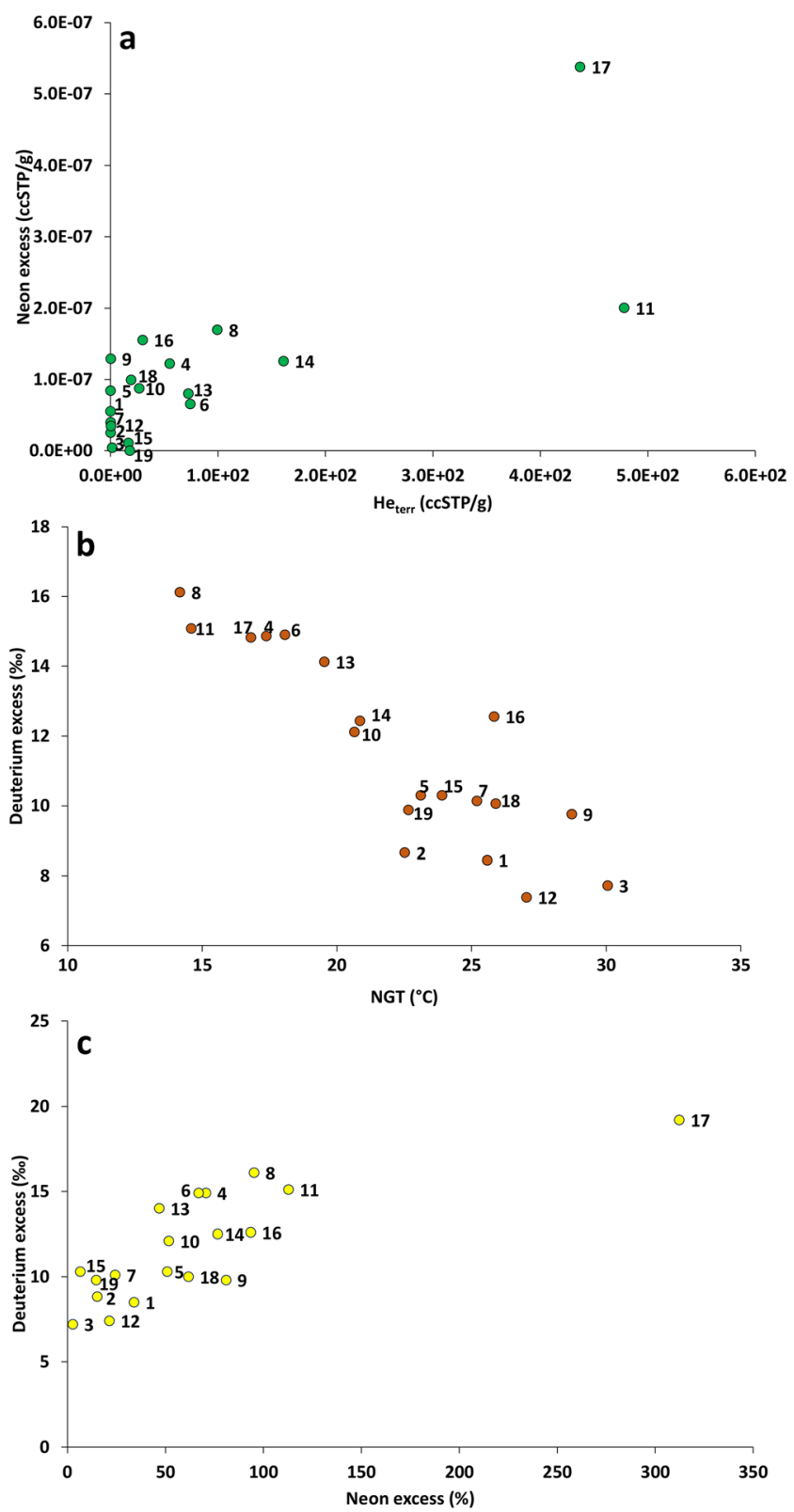

Fig. 4 Plots of a neon excess versus ${ }^{4} \mathrm{He}_{\text {terr }} ; \mathbf{b}$ deuterium excess versus noble gas temperature (NGT); $\mathbf{c}$ deuterium excess versus neon excess

GMWL suggesting a slight degree of surface evaporation. The second group, which includes groundwater samples with terrigenous helium component under $1.92 \cdot 10^{-7} \mathrm{ccSTP} / \mathrm{g}$ is characterised by low $\delta^{18} \mathrm{O}\left(-5.7\right.$ to $-6.3 \%$ ) and $\delta^{2} \mathrm{H}(-37.5$ to $-40.8 \%$ ) values (samples $5,7,9,12,15,18,19)$. On the other hand, the most depleted isotopic signatures of wells with terrigenous helium component above $1.92 \cdot 10^{-7} \mathrm{ccSTP} / \mathrm{g}$ are characterised by low $\delta^{18} \mathrm{O}\left(-6.5\right.$ to $-8.3 \%$ ) and $\delta^{2} \mathrm{H}(-39.6$ to $-47.4 \%$ ) values (samples $4,6,8,10,11,13,14,16,17$ ). These waters show markedly different isotopic signatures, which may be explained by recharge during the late Pleistocene or the transition time between the two epochs
(Holocene-Pleistocene), otherwise mixing with waters that recharged during the late Pleistocene and the Holocene.

\section{Groundwater evolution characteristics}

Besides the clustering of the samples into two groups, one with warm young Holocene recharged water samples and the other with cold old Pleistocene recharged samples, the ${ }^{4} \mathrm{He}_{\text {terr }}$-NGT plot suggests a more continuous NGT evolution with time. Samples 4, 6, 8 were taken in the eastern part of the aquifer and they noticeably do not fit into the warm young cluster, presumably because they have a different groundwater evolution than the western part. Based on the ${ }^{4} \mathrm{He}_{\text {terr }}$-NGT (Fig. 2b) plot, two trends of groundwater evolution can be distinguished, where samples $4,6,8$ represent one group and samples 11, 13, 14, 17 trending towards younger and warmer waters represent another group. These groups can refer to a different component of the aquifer because they can be separated spatially: samples 4, 6, 8 describe the eastern part and samples 11, 13, 14, 17 refer to the western and southwestern part of the Turonian aquifer (Fig. 1).

Noble gas groundwater studies in semiarid regions show a correlation between NGTs and excess air amounts (Aeschbach-Hertig et al. 2002; Beyerle et al. 2003; Ingram et al. 2007; Massmann and Sültenfuss 2008; AeschbachHertig and Solomon 2013). When plotting the excess neon concentration (defined as $\mathrm{Ne}_{\text {measured }}-\mathrm{Ne}_{\text {solubility equilibrium) }}$ as the indicator of the excess air amount and the terrigenous helium concentration, a clear positive correlation can be seen (Fig. 4a). The neon excess is calculated by the mixing corrected values. According to the closed-system equilibration model, the explanation of the higher excess air component might be increased fluctuations of the groundwater level due to intense rainfall events. Because an elevated water table can lead to increased hydrostatic pressure on the entrapped air in the quasi-saturated zone, the neon concentration would increase (Stute and Talma 1998). The increased neon concentration can be connected to the increase of recharge due to the higher amount of intermittent precipitation events that occurred in the recharge area of the Turonian aquifer (Stute and Talma 1998).

Plotting the deuterium excess $\left(d=\delta^{2} \mathrm{H}_{\text {corr }}-8 \cdot \delta^{18} \mathrm{O}_{\text {corr }}\right.$; after Dansgaard 1964) against the NGTs, a clear negative correlation is observed which can be associated to the humidityrelated climate indicator (Pfahl and Sodemann 2014; Table 1; Fig. 4b). Higher NGTs correlates with lower deuterium excess in the groundwater. Additionally, there is a clear correlation between deuterium excess and neon excess (Fig. 4c). The deuterium excess of those waters that recharged during late Pleistocene or during or between early and mid Holocene is above $10 \%$. This high deuterium excess can be explained by reevaporation, which may cause a kinetic isotope enrichment where the fractionation for both ${ }^{18} \mathrm{O}$ and ${ }^{2} \mathrm{H}$ is correlated 
(Clark and Fritz 1997). This phenomenon could explain the high deuterium excess values as a consequence of reevaporation of surface water at the recharge area of the Turonian aquifer, contrary to the recent recharge where the formation of groundwater takes places through heavier rains (Rozanski 1985). Heavy rains indicate higher water level fluctuations, and hence higher neon excess. If precipitation with an average deuterium excess of $10 \% o$ is reevaporated, the lighter ${ }^{2} \mathrm{H}^{1} \mathrm{H}^{16} \mathrm{O}$ molecule would be enriched in the vapor phase, resulting in increased deuterium excess in precipitation.

\section{Conclusions}

A limestone-dolomite aquifer was studied using a multitracer approach $\left(\delta^{18} \mathrm{O}, \delta^{2} \mathrm{H}, \delta^{13} \mathrm{C},{ }^{3} \mathrm{H},{ }^{14} \mathrm{C}\right.$ and noble gases) in the Tadla basin, Morocco. The Turonian aquifer is suitable for a groundwater-based paleoclimate reconstruction, representing the Holocene-late Pleistocene epochs. MRTs of groundwater were calculated using the Pearson radiocarbon model, taking into account the chemical and isotope hydrological parameters and contribution of freshwater. Stable isotope, noble gas and radiocarbon data were used to verify the existence of waters recharged during the late Pleistocene. Noble gas analyses were carried out to determine the temperature difference between the late Pleistocene and Holocene. In addition to the radiocarbon ages, the groundwater samples were clustered into two groups based on $\mathrm{He}_{\text {terr }}$ content, one with warm young Holocene recharged water samples and the other with cold old Pleistocene recharged samples. The NGTs derived for the Holocene samples gave an average of $25.2 \pm 1.3{ }^{\circ} \mathrm{C}$, while the older samples, representing the late Pleistocene, yield a mean NGT of $17.2 \pm 1.7{ }^{\circ} \mathrm{C}$. These ages correspond to glacial periods and the recharge temperatures obtained are significantly lower $\left(8.6 \pm 2.1^{\circ} \mathrm{C}\right)$ than the Holocene temperatures in the Tadla basin. This paleotemperature reconstruction confirms previous groundwater-based studies from the African continent and its surroundings, where a deglacial warming of at least $5-7{ }^{\circ} \mathrm{C}$ has been inferred. A clear positive correlation can be observed between the neon excess and the terrigenous helium. The neon excess can be connected to increased recharge due to a higher amount of intermittent precipitation events indicating that the older groundwater recharged during a wetter period of the past. Further, a clear negative correlation can be found between the deuterium excess and the NGT, which means the higher the NGT the lower the deuterium excess is in the groundwater sample. This connection also supports a colder and wetter climate of the late Pleistocene and the warmer and wetter climate of early and mid-Holocene.
According to the analysis, these aquifers were recharged during interglacial wet periods and it appears that one part of these aquifers recharged during glacial wet periods. The results of this investigation suggest that a similar approach to groundwater studies can be used to address the nature of wet epochs in other regions of North Africa.

Acknowledgements The English editing of the manuscript by Prof. Timothy Jull is highly acknowledged.

Funding information Open access funding provided by MTA Institute for Nuclear Research (MTA ATOMKI). The research was supported by the European Union and Hungary, co-financed by the European Regional Development Fund through the GINOP-2.3.2-15-2016-00009 'ICER' project.

\section{References}

Abouelmagd A, Sultan M, Sturchio NC, Soliman F, Rashed M, Ahmed M, Kehew AE, Milewski A, Chouinard K (2014) Paleoclimate record in the Nubian Sandstone aquifer, Sinai Peninsula, Egypt. Quat Res 81(1):158-167

Aeschbach-Hertig W, Solomon DK (2013) Noble gas thermometry in groundwater hydrology. In: Burnard P (ed) The Noble gases as geochemical tracers. Springer, Heidelberg, Germany, pp 81-122

Aeschbach-Hertig W, Peeters F, Beyerle U, Kipfer K (1999) Interpretation of dissolved atmospheric noble gases in natural waters. Water Resour Res 35:2779-2792

Aeschbach-Hertig W, Peeters F, Beyerle U, Kipfer R (2000) Palaeotemperature reconstruction from noble gases in ground water taking into account equilibration with entrapped air. Nature 405: 1040-1044

Aeschbach-Hertig W, Beyerle U, Holocher J, Peeters F, Kipfer R (2002) Excess air in groundwater as a potential indicator of past environmental changes. In: Study of environmental change using isotope techniques. IAEA, Vienna, pp 174-183

Aeschbach-Hertig W, El-Gamal H, Wieser M, Palcsu L (2008) Modeling excess air and degassing in groundwater by equilibrium partitioning with a gas phase. Water Resour Res 44:449-461

Andrews JN, Fontes J-C, Aranyossy J-F, Dodo A, Edmunds WM, Joseph A, Travi Y (1994) The evolution of alkaline groundwaters in the Continental Intercalaire aquifer of the Irhazer plain, Niger. Water Resour Res 30:45-61

Bartlett MG, Chapman DS, Harris RN (2006) A decade of ground-air temperature tracking at Emigrant Pass Observatory, Utah. J Clim 19(15):3722-3731

Berke MA, Johnson TC, Werne JP, Grice K, Schouten S, Damsté JSS (2012) Molecular records of climate variability and vegetation response since the late Pleistocene in the Lake Victoria basin, East Africa. Quat Sci Rev 55:59-74

Beyerle U, Rueedi J, Leuenberger M, Aeschbach-Hertig W, Peeters F, Kipfer R, Dodo A (2003) Evidence for periods of wetter and cooler climate in the Sahel between 6 and $40 \mathrm{kyr}$ BP derived from groundwater. Geophys Res Lett 30(4):1173

Blaser PC, Coetsiers M, Aeschbach-Hertig W, Kipfer R, Van Camp M, Loosli HH, Walraevens K (2010) A new groundwater radiocarbon correction approach accounting for palaeoclimate conditions during recharge and hydrochemical evolution: the Ledo-Paniselian aquifer, Belgium. Appl Geochem 25(3):437-455

Bouchaou L, Michelot JL, Qurtobi M, Zine N, Gaye CB, Aggarwal PK, Marah H, Zerouali A, Taleb H, Vengosh A (2009) Origin and 
residence time of groundwater in the Tadla basin (Morocco) using multiple isotopic and geochemical tools. J Hydrol 379:323-338

Bouhlassa S (2010) Atlas of isotope hydrology - MOROCCO. AIEA, Durham, NC

Brahim YA, Bouchaou L, Sifeddine A, Khodri M, Reichert B, Cruz FW (2016) Elucidating the climate and topographic controls on stable isotope composition of meteoric waters in Morocco, using stationbased and spatially-interpolated data. J Hydrol 543:305-315

Clark I, Fritz CI (1997) Environmental isotopes in hydrogeology. Lewis, Boca Raton

Dansgaard W (1964) Stable isotopes in precipitation. Tellus 16(4):436468

Darling WG (2011) The isotope hydrology of Quaternary climate change. J Hum Evol 60:417-427. https://doi.org/10.1016/j.jhevol.2010.05. 006

Darling WG, Edmunds WM, Kinniburgh DG, Kotoub S (1987) Sources of recharge to the basal Nubian sandstone aquifer, Butana region, Sudan. In: Isotope techniques in water resources development, vol 1987. International Atomic Energy Agency, Vienna, pp 205-224

de Menocal PB (2014) Marine sediment records of African climate change: progress and puzzles. In: Reference module in earth systems and environmental sciences, from treatise on geochemistry, vol 14, 2nd edn. Elsevier, Amsterdam, pp 99-108

Edmunds WM, Fellman E, Goni IB, McNeill G, Harkness DD (1998) Groundwater, palaeoclimate and palaeorecharge in the Southwest Chad Basin, Borno State, Nigeria. In: Isotope techniques in the study of environmental change. IAEA, Vienna, pp 693-707

Fontes J-C, Garnier JM (1979) Determination of the initial 14C activity of the total dissolved carbon: a review of the existing models and a new approach. Water Resour Res 15:399-413

Fontes JC, Gasse F, Andrews JN (1993) Climatic conditions of Holocene groundwater recharge in the Sahel zone in Africa. In: Isotope techniques in the study of past and current environmental changes in the hydrosphere and the atmosphere. IAEA, Vienna, pp 231-248

Gardner PM, Heilweil VM (2014) A multiple-tracer approach to understanding regional groundwater flow in the Snake Valley area of the eastern Great Basin, USA. Appl Geochem 45:33-49

Geyh MA (2000) An overview of 14C analysis in the study of groundwater. Radiocarbon 42:99-114

Guendouz A, Moulla AS, Edmunds WM, Shand P, Poole J, Zouari K, Mamou A (1998) Paleoclimatic information contained in groundwaters of the Grand Erg Oriental, North Africa. In: Isotope techniques in the study of environmental change. IAEA, Vienna, pp $555-571$

Han LF, Plummer LN (2013) Revision of Fontes \& Garnier's model for the initial ${ }^{14} \mathrm{C}$ content of dissolved inorganic carbon used in groundwater dating. Chem Geol 351:105-114

Heaton THE, Talma AS, Vogel JC (1986) Dissolved gas paleotemperatures and $18 \mathrm{O}$ variations derived from groundwater near Uitenhage, South Africa. Quat Res 25:79-88

IAEA, WMO (2014) Global network of isotopes in precipitation. GNIP database, IAEA, Vienna

Ingerson CW, Pearson FJ (1964) Estimation of age and rate of motion of ground-water by the $14 \mathrm{C}$ method. In: Recent researches in the field of hydrosphere, atmosphere, and nuclear geochemistry. Sugawara Festival Volume. Maruzen, Tokyo, pp 263-283

Ingram RGS, Hiscock KM, Dennis PF (2007) Noble gas excess air applied to distinguish groundwater recharge conditions. Environ Sci Technol 41:1949-1955

Klump S, Tomonaga Y, Kienzler P, Kinzelbach W, Baumann T, Imboden DM, Kipfer R (2007) Field experiments yield new insights into gas exchange and excess air formation in natural porous media. Geochim Cosmochim Acta 71(6):1385-1397

Kulongoski JT, Hilton DR, Selaolo ET (2004) Climate variability in the Botswana Kalahari from the late Pleistocene to the present day. Geophys Res Lett 31(10)
Loomis SE, Russell JM, Ladd B, Street-Perrott FA, Damsté JSS (2012) Calibration and application of the branched GDGT temperature proxy on East African lake sediments. Earth Planetary Sci Lett $357: 277-288$

Marah H (2007) Liquid scintillation low level tritium measurement in water. Phys Chem News (37):20-24

Martrat B, Grimalt JO, Lopez-Martinez C, Cacho I, Sierro FJ, Flores JA, Zahn R, Canals M, Curtis JH, Hodell DA (2004) Abrupt temperature changes in the Western Mediterranean over the past 250,000 years. Science 306(5702):1762-1765

Massmann G, Sültenfuss J (2008) Identification of processes affecting excess air formation during natural bank filtration and managed aquifer recharge. J Hydrol 359:235-246

Molnár M, Janovics R, Major I, Orsovszk J, Gönczi R, Veres M, Leonar AG, Castle SM, Lange TE, Wacker L, Hajdas I (2013a) Status report of the new AMS $14 \mathrm{C}$ sample preparation lab of the Hertelendi Laboratory of Environmental Studies (Debrecen, Hungary). Radiocarbon 55(2):665-676

Molnár M, Rinyu L, Veres M, Seiler M, Wacker L, Synal HA (2013b) EnvironMICADAS: a mini 14 C AMS with enhanced gas ion source Interface in the Hertelendi Laboratory of Environmental Studies (HEKAL), Hungary. Radiocarbon 55(2):338-344

Mook WG (1980) Carbon-14 in hydrogeological studies. In: Fritz P, Fontes JC (eds) Handbook of environmental isotope geochemistry. Elsevier, Amsterdam 1:49-74

Mook WG (2000) Environmental isotopes in the hydrological cycle: principles and applications. In: International Hydrological Programme (IHP-V). Technical documents in hydrology, IAEA, Vienna and UNESCO, Paris

Papp L, Palcsu L, Major Z, Rinyu L, Tóth I (2012) A mass spectrometric line for tritium analysis of water and noble gas measurements from different water amounts in the range of microlitres and millilitres. Isot Environ Health Stud 48(1):494-511

Peeters F, Beyerle U, Aeschbach-Hertig W, Holocher J, Brennwald MS, Kipfer R (2003) Improving noble gas based paleoclimate reconstruction and groundwater dating using ${ }^{20} \mathrm{Ne} /{ }^{22} \mathrm{Ne}$ ratios. Geochim Cosmochim Acta 67:587-600

Pfahl S, Sodemann H (2014) What controls deuterium excess in global precipitation? Clim Past 10(2):771-781

Plummer LN, Glynn PD (2013) Radiocarbon dating in groundwater systems. In: Isotope methods for dating old groundwaters, chap 4. IAEA, Vienna, pp 33-90

Rinyu L, Molnár M, Major I, Nagy T, Veres M, Kimák Á, Wacke L, Synal HA (2013) Optimization of sealed tube graphitization method for environmental C-14 studies using MICADAS. Nucl Instrum Methods Phys Res, Sect B 294:270-275

Rozanski K (1985) Deuterium and oxygen-18 in European groundwaters: links to atmospheric circulation in the past. Chem Geol 52(3-4): 349-363

Rudolph J, Rath HK, Sonntag C (1984) Noble gases and stable isotopes in $14 \mathrm{C}$ dated palaeowaters from Central Europe and the Sahara. In: Isotope hydrology. IAEA, Vienna 1983:467-477

Saadi R, Túri M, Palcsu L, Marah H, Oum KH, Rinyu L, Molnár M, Futó I (2017) A potential groundwater aquifer for palaeoclimate reconstruction: Turonian aquifer, Tadla basin, Morocco. J Afr Earth Sci 132:64-71

Salem O, Visser JH, Dray M, Gonfiantini R (1980) Environmental isotopes used in hydrogeological study of north-eastern Brazil. In: Arid-zone hydrology: investigations with isotope techniques, panel proceedings series (1980). IAEA, Vienna, p 134

Solomon DK (2000) ${ }^{4} \mathrm{He}$ in groundwater, Environmental tracers in subsurface hydrology. Springer, New York, pp 425-439

Stuiver M, Grootes P (2000) GISP2 oxygen isotope ratios. Quat Res 53(3):277-284

Stute M, Schlosser P (1993) Principles and applications of the noble gas paleothermometer. In: AGU monograph on climate change in 
continental isotopic, records, geophysical monograph, vol 78, pp $89-100$

Stute M, Talma AS (1998) Glacial temperatures and moisture transport regimes reconstructed from noble gases and $\delta^{18} \mathrm{O}$, Stampriet aquifer, Namibia. In: Isotope techniques in the study of environmental change. IAEA, Vienna

Stute M, Clark JF, Schlosser P, Broecker WS, Bonani G (1995) A 30, $000 \mathrm{yr}$ continental paleotemperature record derived from noble gases dissolved in groundwater from the San Juan Basin, New Mexico. Quat Res 43:209-220

Tammal M, Kili M, Gasmi H, El Mridekh A, El Mansouri B (2014) Modélisation multicouche du système aquifère du bassin de Tadla et le plateau des phosphates [Modeling multi-aquifer system of Tadla basin and plateau of phosphates]. Int J Innov Sci Res 6(2): $172-180$

Torgersen T, Stute M (2013) Helium (and other noble gases) as a tool for understanding long timescale groundwater transport. In: Isotope methods for dating old groundwater, chap 8. IAEA, Vienna
Varsányi I, Palcsu L, Kovács LÓ (2011) Groundwater flow system as an archive of palaeotemperature: noble gas, radiocarbon, stable isotope and geochemical study in the Pannonian Basin, Hungary. Appl Geochem 26(1):91-104

Vodila G, Palcsu L, Futó I, Zs S (2011) A 9-year record of stable isotope ratios of precipitation in eastern Hungary: implications on isotope hydrology and regional palaeoclimatology. J Hydrol 400:144-153

Wacker L, Christl M, Synal HA (2010) BATS: a new tool for AMS data reduction. Nucl Instrum Methods Phys Res, Sect B 268(7-8):976979

Weyhenmeyer CE, Burns SJ, Waber HN, Aeschbach-Hertig W, Kipfer R, Loosli HH, Matter A (2000) Cool glacial temperatures and changes in moisture source recorded in Oman groundwaters. Science 287(5454):842-845

Wu J, Liu Z, Stuut JBW, Zhao Y, Schirone A, de Lange GJ (2017) NorthAfrican paleodrainage discharges to the Central Mediterranean during the last 18,000 years: a multiproxy characterization. Quat Sci Rev 163:95-113 